DOI:

Cite this as:

Fovet, F. Access, Universal Design and Sustainability of Teaching Practices: a Powerful Synchronicity of

Concepts at a Crucial Conjuncture for Higher Education. Indonesian Journal of Disability Studies (IJDS).2017:

Vol. 04(02): PP 118-129.

\title{
Access, Universal Design and the Sustainability of Teaching Practices: a Powerful Synchronicity of Concepts at a Crucial Conjuncture for Higher Education
}

\author{
${ }^{1 *}$ Frederic Fovet \\ ${ }^{1}$ Faculty of Education, University of Prince Edward Island, Charlottetown, Canada
}

\begin{abstract}
Sustainability in Higher Education is usually interpreted as a concept applying solely to operations management and energy policy. Though the applicability of the concept to social justice is immediately tangible, few campuses have found organic and pragmatic ways to extend principles of sustainability to their equity, diversity or inclusion practices, or to convince their community of the need to do so. This study examines the unique experience of North American campus having attempted this progressive osmosis between the two concepts. Access has represented the opportunity for this rethink. As individual, retroactive accommodations become increasingly obsolete when it comes to providing access to learning to large number of students with specific needs entering post-secondary education, sustainability has become an increasingly appealing lens with which to devise a new framework for inclusion seeking systemic change in pedagogical practices. The North American campus in question implemented a proactive drive for the implementation of Universal Design for Learning from 2011 and this paper presents the analysis of the various and complex ways access and sustainability have become entwined in campus policies. The outcomes are particularly relevant for the Global South in that it may encourage Higher Education institutions in developing countries to avoid the temporary appeal of medical model based measures of inclusion and the precedents set in the Global North over the last two decades, and to focus instead on social model based policies that seek the development of sustainable and inclusive teaching practices from the onset.
\end{abstract}

Keywords: Universal Design for Learning, Inclusion, access, sustainability

\section{Introduction}

This paper presents a unique campus experience which has led to the progressive fusion of the concepts of access and sustainability through a proactive rethink of inclusion policies and practices. In 2011 the campus in question examined decided that it was time to translate the social model of disability (Barnes, Oliver and Barton, 2002) it embraced in its policy statement into actual access practices. This led to the emergence of a rapid and proactive implementation drive for

* Corresponding author: Frederic Fovet

ffovet@upei.ca

Published online at http://IJDS.ub.ac.id/

Copyright $\odot$ 2017PSLD UB Publishing. All Rights Reserved
Universal Design for Learning (UDL) across the campus. As this drive unfolded, grew and eventually led to systemic changes, a tangible degree of synchronicity between access and sustainability began to be perceived and described by the stakeholders involved. The hypothesis of this paper is that both agendas gain momentum on higher education campuses, once these discourses succeed in establishing organic connections between each other within campus policy, literature and forums. The study analyses qualitative data collected from a variety of campus stakeholders over a period of two years. It establishes a link between a number of essential strategic connections between the disability service provider and the sustainability office of this university, and the 
establishment of an osmotic link between both agendas in campus policies.

\section{Context}

The context for the paper is a recent global rethink of disability service provision in higher education, in line with the paradigm shift which has occurred over the last two decades from a medical approach to disability (Bickenbach, Chatterji, Badley \& Ustun, 1999) to the adoption of the social model (Swain \& French, 2000). This has not been a rapid process and post-secondary institutions have, for the great part, at first seemingly embraced the social model of disability without in reality changing access practices (Harrison, 2006). It is in fact the strategic realization that retrofitting could no longer function in higher education, in light of the huge and ever increasingly volume of students experiencing barriers in access to learning, which has led institutions to renew their commitment to inclusive measures (Wagner, Cameto \& Newman, 2003; Houghton \& Fovet, 2012). The most popular tool adopted by universities to address this shift has been Universal Design for Learning (UDL) (Gradel \& Edson, 2010). It is the practical translation of the principles of the social model but also addresses campuses' concerns with strategic planning, growth and the sustainable management of demand for access (Colorado State University, 2013). The stage was historically speaking set from this point on, for possible synchronicity between both concepts.

\section{Literature Review}

The task of developing a literature review is complex in an article of this sort as the topic bridges two widely different fields. There can therefore be no assumption as to reader expertise in either field. This section will attempt to provide sufficient background information on both Universal Design and Sustainability to allow the reader to grasp the full width of existing literature coming into play.

\subsection{The Reframing of Access in Higher Education}

The reframing of access in higher education has increased in tempo in the last few years (Swain, French, Barnes \& Thomas,

Cite this as:

Fovet, F. T Access, Universal Design and the Sustainability of Teaching Practices: a Powerful Synchronicity of Concepts at a Crucial Conjuncture for Higher Education. Indonesian Journal of Disability Studies (IJDS).2017:

Vol. 04(02): pp117-128
2004). The post-secondary sector in North America is moving away from a format of management of Disability issues focused in individual diagnosis and retrofitting on a case by case basis, to an approach more explicitly focused on institutional practices and proactive inclusive access (Mole, 2012). Some arguments for rapid change are grounded, as discussed above, in a growing awareness of the social model (Brown \& Simpson, 2004). Other arguments, however, emerging from the literature seem to have as much impact on the recent openness to change demonstrated by many post-secondary institutions: changing demographics, resource management, efficiency efforts and strategic planning appear as strong triggers to the rethink process occurring across North American campuses (Artiles, 2003; Brown \& Parekh, 2010; Alcorn MacKay, 2010). Sustainability does appear in the literature on paradigm shift in the sense that practitioners are realizing that old models are obsolete and no longer allow for sustainable management of demand (Houghton \& Fovet, 2012).

\subsection{Benefits of UDL for Wider Participation}

Universal Design for Learning (UDL) shows growing promise in the literature as an answer to concerns about the shift in paradigm in the management of Disability in Higher Education (Strange \& Banning, 2001). It also offers satisfactory answers to the strategic worries most institutions have in terms of logistic management of demand, because it focuses interventions on the classroom rather than the individual requests for access (Rose, Harbour, Johnston, Daley \& Abarbanell, 2006). UDL in fact is not an entirely new model per se and it echoes many notions which are already popular in education such as theory on inclusion (Lenz, Deshler \& Kissam, 2004), differentiated teaching literature (Tomlinson, 2001) and findings on multiple intelligence (Hatch \& Gardner, 1993). The implementation of UDL merges these theoretical approaches to inclusion into a userfriendly framework that allows teachers and administrators to engage into a reflection on the accessibility of their practices (Al-Azawei, Serenelli \& Lundqvist, 2016). UDL is also appealingly compatible with a growing interest in the educational use of virtual and 
technological platforms and tools (Weigel, 2002). It is a technology rich framework for the management of Disability, which seems appropriately able to cope and integrate modernity, technological use and IT innovation (Rose, Meyer \& Hitchcock, 2005). In this sense too, organic links begin to appear between notions of sustainable technological change and access (InterAcademy Council, 2004).

\subsection{Benefits of UDL for Wider Participation}

UDL is a solution to the demands of disability management in higher education, but its benefits go far beyond students with disabilities. By triggering a rethink of pedagogy, it enriches the quality of teaching generally and offers assistance to a multitude of diverse students (Bowe, 2000). The literature demonstrating the benefits of UDL implementation in promoting diversity in the student body is growing (Tegmark-Chita, Gravel, Serpa, Domings \& Rose, 2012); in that sense UDL research aligns itself with a discourse on sustainability in higher education which questions the future role of these institutions and wishes to see them become vehicles for social advancement and for the growth of diversity (Swail, Redd \& Perna, 2003).

\subsection{Sustainability of Campus Practices}

At the other end of the spectrum, the literature on sustainability, which has previously been mostly concerned with operations management and energy preservation, is now beginning to consider the applicability of its core concepts to the field of social justice (Ketschau, 2015). Institutions and organizations are increasingly pushed to consider the sustainability of, not just their economic survival, but also of their governance, entrepreneurial style and ethical focus (Gerlach, 2003; Cohen \& Winn, 2007). In Higher Education this has manifested itself as a wider interpretation of sustainability that includes a complex and wide spectrum of social justice dimensions: (Ball, 1999; Moore, 2005). It has meant that administrations have increasingly been willing to examine campus service provision (Alshuwaikhat \& Bubakar,
2008), and even teaching practices (Sterling, 2001), through the lens of sustainability. When such concerns are voiced in the field of Access and Inclusion, UDL readily appears as an appropriate tool because the change it focuses on is systemic and sustainable, as opposed to retrofitting for individual students which has traditionally been a repeated, consumable process (Mole \& Fovet, 2013).

\section{Methodology}

The study presents the analysis of qualitative data collected through a two year initiative seeking full UDL implementation on a Canadian campus. The university classifies itself as a teaching and research institution and has a student population of over 40,000 students.

The data collected was of two types. One part of the data collection and analysis used narrative methodology (Swap, Leonard, Shields \& Abrams, 2001) and focused on the narrative of various campus partners involved in this effort: staff of the disability service provider mostly but also included narratives from staff of other student services units and of the sustainability office itself. Narrative methodology has established itself as a pertinent and rich method of data collection and analysis within processes of organizational change (Snowden, 2000). Much of this data was collected as part of retroactive feedback obtained during or at the end of UD professional development exercises. These forums have varied from the very large (such as the presentation to the executive bodies of the university) to more modest gatherings such as a round table of deans and faculty chairs; the data also originates from feedback given during UDL workshops offered to staff and students.

In later instances, data has also been generated by ongoing consultancy work carried out by the disability unit for specific faculties towards the redesign of courses and evaluations in line with UDL principles. A significant degree of triangulation has occurred through this process (Thurmond, 2001) and this constitutes a cornerstone of the qualitative processes used here: indeed the UD material has substantially evolved during the 
promotional drive, in light of continuing faculty feedback and reactions.

A second distinct fold in the data collection and analysis used discourse analysis (Leitch \& Palmer, 2010) and focused on documents produced by both the accessibility office and the sustainability office. In the case of the sustainability partner, the documents consisted mostly of a sustainability plan establishing 2020 goals for the institutions. In the case of the accessibility office, this was centered primarily around the redesign of the website of the unit, the revamping of its mission statement, and of some of the videos it created within the UDL implementation drive that took place over these two years.

The data collection was ethnographic in nature (Britten, Campbell, Pope, Donovan, Morgan, Pill, 2002), in the sense that many participants expanded on their views, perceptions, and intentions while they were involved in the processes of change described here. In many instances during the two years of the study, the methodology even became participatory action research to some extent (Reason \& Bradbury, 2001; Kelly \& van der Riet, 2001), since many respondents, such as the staff of the sustainability office and the accessibility office, became invested themselves in exploring the links between sustainability and access.

\section{Findings}

The data analysis process involved a manual process of coding (Sutton \& Austin, 2015). As first waves of data began to be collected, a manual coding was carried out on this preliminary raw data. This process was carried again subsequently and the results of these two coding exercises led to the selection of 4 themes which seemed to provide a good overview of the data collected and issues raised, and allow for a rich exploration and analysis of this qualitative data. The data was later categorized under these four themes, and mined and organized in order to produce a rich insight into the stakeholders' perceptions through the process of UDL implementation described (Sadana, 2009). losing chapter contain about conclusions that answer the problem addressed. There is a value of the measurement and processing that became the basis of analysis and discussion.

\subsection{Understanding Access from a Sustainability Lens}

The UDL implementation drive led most of the stakeholders involved to a major reexamination of access policies and a renewed perception of inclusion. Until the UDL implementation drive began, the campus as a whole viewed matters of access as being (i) within the sole ownership of the disability service provider unit, (ii) a static phenomenon involving a steady and insignificant percentage of the student population, and (iii) a management issue requiring no forward planning. The figures and statistics used as part of the UDL drive, relating to changes in demographics of the population of higher education students experiencing barriers in access to learning, quickly convinced the campus stakeholders consulted of the need to review their reliance on these three presumptions. Faced with the needs to provide improved and enhanced access to learning to an ever increasing percentage of the student body with funds that are unlikely to increase proportionately, the imperative to do 'more with less' becomes a pressing reality for the professional on this campus involved in access and disability. The participants consulted reacted enthusiastically to the notion that UDL, by targeting a systemic change in teaching practices rather than a reliance on continuous retrofitting, was a framework likely to yield sustainable results. Senior administrators were particularly receptive to this argument for rapid UDL adoption.

\subsection{Constructing Management of Change in Disability Service Provision through the Lens of Sustainability}

It is important to realize that UDL implementation is not solely dependent on campus wide adoption; it is, in the first instance, dependent on the disability service provider itself reconsidering its practices and 
integrating the framework and the principles it advocates, in order to permanently do away with the medical or deficit model (Harry \& Klingner, 2007) as the basis for its interventions with students. Through this process, the DS provider became increasingly concerned with a disparity between its external campus message and its internal practices.

A year into this campus wide UD implementation effort, the unit decided to assess the implementation of its own access guidelines on its internal procedures, in the form of a UD audit (Beck, Diaz del Castillo, Fovet, Mole \& Noga, 2014). The audit was planned as a progressive, ongoing professional development exercise. The motivational factors that led to this decision were the following: (i) a desire for increased consistency between external messaging and internal procedures; (ii) transparency with students and concern vis-à-vis users that procedures were having a contradictory effect; (iii) a social justice preoccupation that procedures were not only restricting access, but allowing power and privilege dynamics to be deployed within the service provision framework.

The management of change process described above is not an easy task and it encountered resistance from staff members, as most radical work environment shifts usually do (Smollan, 2011). The data collected from the staff of the disability service provider, however, identifies sustainability as being the most important argument in easing the process of change with the workforce involved. As a rule it was the notion of sustainability that led staff members to eventually embrace the changes proposed to their office procedures, rather than the social model argument relating to the construction of disability. Sustainability literally became the change agent which allowed the shift towards the social model implementation to occur.

\subsection{Extending the Notion of}

Cite this as:

Fovet, F. T Access, Universal Design and the Sustainability of Teaching Practices: a Powerful Synchronicity of Concepts at a Crucial Conjuncture for Higher Education. Indonesian Journal of Disability Studies (IJDS).2017:

Vol. 04(02): pp117-128

\section{Sustainability to Teaching Practices}

With participants who were instructors or those trained as pedagogues working in other capacities, presenting UDL implementation as a move towards social sustainability had a wide impact. The resistance of instructors to the UDL framework is well documented in the literature (Edyburn, 2010; Anstead, 2016). The initial adoption of the more accessible practices in teaching and evaluation encouraged by the UDL model indeed represents a significant investment of time and resources on their part. Across North America, lobbying for UDL implementation on higher education campuses has therefore not been an easy task (Harrison, 2006); it has required research around this resistance per se and the analysis of complex variable related to management of change in pedagogy (Anstead, 2016; Shulman \& Shulman, 2007). The researcher found that instructors on the other hand were particular receptive to the presentation of this change process as a move towards more sustainable teaching practices. It is a lens that has evidently rarely been presented to instructors and it acts as a facilitator in the implementation process. When UDL implementation is presented as a change which requires initial investment, but pays off in the long term by reducing later requirement for retrofitting, there is much more buy-in from instructors (Ralabate, 2011). The concept of sustainable teaching practice is one that creates significant interest and good will within this change process.

\subsection{Extending Interpretations of Sustainability Beyond Operations}

Sustainability still has, much like Disability, the status of 'minority' dialogue on many North American campuses (Goodman, 2001). While sustainability offices struggle to evidence the need for campus wide policies and planning with regards to the sustainability of higher education, it is often with great difficulties that this discourse reaches any visibility (Wals \& Jickling, 2002). Within the 
process of UDL implementation, sustainability officers and staff commented that their own agenda was gaining momentum through the highlighted synchronicity between sustainability and access. It also specifically allowed them to illustrate to the campus the fact that sustainability also has an impact on the attainment of social justice. The title of the annual Disability Awareness Week of the campus in 2013 was 'Inclusion: celebrating sustainable campus practices' and the framing of this event illustrates admirably the reciprocal gain which both units were able to achieve by joining voices.

Interestingly, the responses of student participants suggest that the parallel and connections between sustainability and access are organic and seamless to them. The disability service provider has created a tradition of naming its summer interns 'sustainability interns' because they habitually work on further implementation of UDL throughout the campus. Far from questioning this terminology, the interns during successive years have been able to describe the reason why their position carries this name, and to eloquently verbalize the links between the work of both offices. They have, over repeated summers, worked on access issues while perceiving and describing themselves as sustainability agents.

\section{Outcomes}

The outcomes of this analysis are numerous and wide ranging. We will present them from a series of perspectives: (i) outcomes for the future of access in higher education; (ii) outcome for the development of the sustainability agenda in higher education; (iii) lessons in collaboration; (iv) lessons for growth for minority discourse advocates in a neoliberal post-secondary conjuncture; and (iv) reflection from the perspective of the Global South.

\subsection{Outcomes for the Future of Access in Higher Education}

For many years, the disability discourse has been a minority agenda on post-secondary campuses; it has been firmly anchored in Critical Theory and has involved only a minority of actors and sadly reached few people (Hiranandani, 2005). UDL offers disability activists in higher education the opportunity to offer access solutions which have relevance to a wide student body because they remove barriers for all students (Howard, 2004). This allows post-secondary disability service providers to transform their message from a minority discourse to one that has immediate appeal to the entire campus community. It is clear that the parallels and the links that connect UDL and sustainability have facilitated this transformation and increased the visibility and relevance of the UDL model. It can be said that both the Sustainability and Disability discourses, which are traditionally minority discourses in Higher Education, have here gained momentum from the synchronicity and together evolved to a majority discourse. This is an observation and a conceptualization that is transferable to other campuses. It will yield important strategic guidance to many Higher Ed stakeholders on how to construct successful partnership in order to gain visibility and change.

\subsection{Outcomes for the Development of the Sustainability Agenda in Higher Education}

The sustainability movement in higher education is in full transformation (Wals, 2007). Its stakeholders and advocates have realized that its relevance is not limited to a minority within the campus community, provided it becomes able to verbalize its links to social justice (Glasser, 2007). UDL is instrumental in easing and speeding up this process of association. By joining forces with a disability service provider, this specific sustainability office has found a way to widen the impact of its message and to trigger - very rapidly - a wider interpretation of the notion of sustainability. It is suggested that a similar process can take place on other campuses, in much the same way, and that this experience is transferable to other postsecondary environments (Holmberg \& Samuelsson, 2006; Scholz, Lang, Wiek et al., 2006).

\subsection{Lesson in Collaboration}

This study is also the analysis of a successful experience in collaboration, a collaboration between unprecedented partners. Many agents of change on post-secondary campuses, such as disability service providers, diversity and equity offices, teaching and 
learning support offices and sustainability units, still to this day work in silos (Lloyd, 2016). Creating organic collaborations does not come naturally in the post-secondary landscape and it is a process many stakeholders must learn to develop proactively (Schroeder, 1999). In this specific instance the challenge was even more considerable because few people would see readily visible connections between Sustainability and Access. The campus experience detailed here shows that the recipe for success in establishing these mutually beneficial collaborations is conscious and progressive bridge building between new partners (Kleemann, 2005). It requires a global, systemic view of change management in postsecondary education and an understanding of the investment required to create a global institution shift that is larger than unit agendas. In many ways it can be said that it is this search for allegiances and partnerships, that allows such social justice actors to benefit from current neoliberal pressures transforming higher education (Olssen \& Peters, 2005), rather than fall victim to them (Cooper, 2009).

\subsection{Lessons for Growth for Minority Discourse Advocates in a Neoliberal Post-secondary Landscape}

Disability has inherently been a minority discourse within the North American Higher Ed landscape ever since it made its appearance in the late 70s as a result of the Civil Rights movement and the key legislation that followed - such as the ADA and the Charter of Rights (Madaus, 2011). Despite growing numbers of demands for services and a percentage of the campus population registered with accessibility offices often reaching close to 10 percent (Lovett, Nelson \& Lindstrom, 2014), Disability continues to be seen as a minority discourse, primarily because of the Critical Theory objectives that constitute its foundation (Bone, 2017). Universal Design for Learning of itself has the potential to shift the Higher Ed Disability discourse out of this minority status, and to offer it a wider audience, by evidencing the relevance to all learners of the reflection on pedagogy it encourages (Heelan, 2015). Importantly though this study shows that UDL must be promoted beyond the sphere of accessibility services and that the stakeholders

Cite this as:

Fovet, F. T Access, Universal Design and the Sustainability of Teaching Practices: a Powerful Synchronicity of Concepts at a Crucial Conjuncture for Higher Education. Indonesian Journal of Disability Studies (IJDS).2017:

Vol. 04(02): pp117-128 claiming ownership over it must go far beyond simply Disability service providers. By highlighting an unusual allegiance between an accessibility service and a sustainability office, the paper charts a course for the development of strategic alliances that transform the very nature of the Disability discourse on Higher Ed campuses.

\subsection{Reflection in the Context of the Global South}

This study has wider relevance on a global landscape of internationalization. There is growing osmosis between the Global North and the Global South on issues of Disability (Fisher, Shang \& Xie, 2016), and many developing countries observe and reflect on how best to implement inclusive practices on their post-secondary campuses. In doing so there is a natural tendency to examine and seek to duplicate the developments that have followed the Civil Right movement in the United States and Canada, and to adopt many of the provisions that have been put in place on campuses as a result of Human Rights legislation (Meekosha \& Soldatic, 2011; Madaus, 2011). The great majority of these provisions, however, amount to retrofitting and - thirty years - on most North-American campuses are being confronted by the limitations of such frameworks and provisions (Kelly \& Hess, 2011).

There are perhaps two myths that this paper may assist in debunking. First, the implicit dynamics of post-colonialism need to be dissected and exposed (Sidhu, 2015). The Global North may not have relevant solutions to offer the Global South and its postsecondary institutions when it comes to access and inclusion. This is particularly evident when the post-secondary environment in developed countries current laments its inability to address the needs of students with Disabilities, and its resistance to a shift towards Social Model provisions (Department of Social Services, 2012). There is undoubtedly some virtue in encouraging developing countries to carry out their own reflection with regards to access and Higher Education, as part of a process of 'decolonization' of the curriculum (Legrange, 2016). The errors of the past decades - which are coming to light in the current North 
American post-secondary landscape - need not be unnecessarily repeated (Swart \& Pettipher, 2011). A move straight to social model implementation is highly preferable and more sustainable.

Second, linking Accessibility and Disability to the notions of Sustainability is a perspective that might be more congenial to developing countries than they are to countries within the Global North (Reid \& Petocz, 2006). The variable most often discussed in this field of Disability management, or pedagogy generally, in Higher Ed is indeed 'resistance to change' (Bryant, Coombs \& Pazio, 2014); countries that are not battling historical traditions as a woven feature of the Higher Ed fabric, or the inherent conservatism of long established institutions, may have more ease in associating concepts of Sustainability and Access proactively, rapidly and successfully (Elshof, 2005). This paper therefore stands as a reminder to postsecondary institutions of the Global South that Disability, Access and Sustainability can readily be associated and developed side by side in strategic development for the 21st century (Ilieva, Beck \& Waterstone, 2014). There are shortcuts evidenced here that are available to post-secondary institutions of the Global South not yet anchored or entangled in ableist visions when it comes to pedagogy, inclusion and access to learning.

\section{Bibliography}

Alcorn MacKay, S. (2010) Identifying Trends and Supports for Students with Autism Spectrum Disorder Transitioning into Postsecondary. Higher education Quality Council of Ontario, Toronto.

Al-Azawei, A., Serenelli, F., \& Lundqvist, K. (2016) 'Universal Design for Learning (UDL): A Content Analysis of Peer Reviewed Journal Papers from 2012 to 2015'. Journal of the Scholarship of Teaching and Learning, Vol. 16(3), Page 39-56.

Anstead, M. (2016) Teachers Perceptions of Barriers to Universal Design for Learning. Dr. Peter Ross, Dr. Jo DeSoto, \& Dr. Karen Hunt,

Cite this as:

Fovet, F. T Access, Universal Design and the Sustainability of Teaching Practices: a Powerful Synchronicity of Concepts at a Crucial Conjuncture for Higher Education. Indonesian Journal of Disability Studies (IJDS).2017:

Vol. 04(02): pp117-128
EdD Thesis. Faculty of education, Walden University.

Artiles, A. (2003). 'Special education's changing identity: Paradoxes and dilemmas in views of culture and space'. Harvard Educational Review, Vol. 73(2), Page. 177202.

Alshuwaikhat, H., \& Bubakar, I. (2008) 'An integrated approach to achieving campus sustainability: Assesment of the current campus environmental management practices'. Proceedings of the 4th International Barcelona Conference on Higher Education, Vol.7. Higher education for sustainable development. Barcelona: GUNI. http://www.guni-rmies.net (Accessed December 1st, 2013)

Ball, G. D. S. (1999). 'Building a sustainable future through transformation'. Futures, Vol. 31, Page. 251-270

Barnes, C. Oliver, M. and Barton, L. (2002) 'Disability, the Academy and the Inclusive Society'. In C. Barnes, M. Oliver and L. Barton (eds.) Disability Studies Today, Cambridge: Polity, Page 250-260.

Beck, T., Diaz del Castillo, P., Fovet, F., Mole, H., \& Noga, B. (2014) 'Applying Universal Design to disability service provision: outcome analysis of a UD audit'. Journal of Post-secondary Education and Disability, Vol. 27(2), Page 209-222

Bickenbach, J., Chatterji, I., Badley, E. and Ustun T. (1999) 'Models of Disablement, Universalism and the International Classification of Impairments, Disabilities and Handicaps'. Social Science \& Medicine, Vol. 48(9), Page. 1173-1187

Bone, K.M. (2017) 'Trapped behind the glass: crip theory and disability identity'. Disability \& Society, Vol. 32 (9), Page 1297-1314

Bowe, F. G. (2000). Universal Design in Education: Teaching Non-Traditional Students. Westport, CT: Bergin \& Garvey.

Britten, N., Campbell, R., Pope, C., Donovan, J., Morgan, M., \& Pill, R. (2002) 'Using metaethnography to synthesise qualitative research: 
a worked example'. Journal of Health Services Research and Policy, Vol. 7, Page. 209-15

Brown, R. \& Parekh, G. (2010) Special Education: Structural Overview and Student Demographics, Research Report. Toronto: Research and Information Services, Toronto District School Board.

Brown, P. \& Simpson, A. (2004) 'The Social Model of Disability in Higher Education: attention to tensions'. In: C. Barnes and G. Mercer G. (Eds. ) Disability Policy and Practice: Applying the Social Model, Leeds: The Disability Press, Page. $65-81$.

Bryant, P., Coombs, A., \& Pazio, M. (2014) 'Are We Having Fun Yet? Institutional Resistance and the Introduction of Play and Experimentation into Learning Innovation through Social Media'. Journal of Interactive Media in Education, Vol. 2, Article 4

Cohen, B., \& Winn, M.I. (2007) 'Market imperfections, opportunity and Sustainable Entrepreneurship.' Journal of Business Venturing, Vol. 22(1), Page. 29-49.

Colorado State University (2013) Institutionalizing UDL: How to Implement UDL and Make It Sustainable! (WWW) http://accessproject.colostate.edu/presentations /udl/consortium/june_08/workshop.php (accessed on August 19th, 2013)

Cooper, M. (2009) 'Changing the Culture of the Campus: Towards an Inclusive Higher Education - Ten Years on'. Conference Proceedings, European Access Network conference - York.

Department of Social Services (2012) Shut out: The Experience of People with Disabilities and their Families in Australia. Government of Australia, Canberra.

Edyburn, D. L. (2010). 'Would you recognize universal design for learning if you saw it? Ten propositions for new directions for the second decade of UDL'. Learning Disability Quarterly, Vol. 33, Page 33-41.
Elshof, L. (2005). 'Teacher's Interpretation of Sustainable Development'. International Journal of Technology and Design Education, Vol. 15(2), Page 173-186

Fisher, K.R., Shang, X., \& Xie J. (2016) Global South-North Partnerships: Intercultural Methodologies in Disability Research. In: Grech S., Soldatic K. (Eds) Disability in the Global South. International Perspectives on Social Policy, Administration, and Practice. Springer, Cham

Gerlach, A. (2003) Sustainable Entrepreneurship and Innovation. In: University of Leeds: The 2003 Corporate Social Responsibility and Environmental Management Conference. Leeds, UK: University of Leeds, Page. 101-110.

Glasser, H. (2007) Minding the gap: the role of social learning in linking our stated desire for a more sustainable world to our everyday actions and policies. In Wals, A.E.J. (Ed.) Social Learning towards a Sustainable World. Principles, Perspectives, and Praxis (Page..3562). Wageningen, The Netherlands: Wageningen Publishers.

Goodman, D.]. (2001) Promoting Diversity and Social Justice: Educating People from Privileged Groups. Thousand Oaks, CA: Sage Publications.

Gradel, K., \& Edson, A. J. (2010). 'Putting universal design for learning on the higher ed agenda.' Journal of Educational Technology Systems, Vol. 38(2), Page. 111-121

Harrison, E. (2006) 'Working with Faculty Toward Universally Designed Instruction: The Process of Dynamic Course Design', Journal of Postsecondary Education and Disability, Special Issue: Universal Design in Higher Education, Vol. 19 (2), Page. 152 - 162

Harry, B., \& Klingner, J. (2007) 'Discarding the Deficit Model'. Improving Instruction for Students with Learning Needs, Vol. 64 (5), Page. 16-21

Hatch, T. \& Gardner, H. (1993) 'Finding cognition in the classroom: an expanded view of human intelligence'. In: G. Salomon (Ed.) 
Distributed Cognitions. Psychological and Educational Considerations, Cambridge: Cambridge University Press.

Heelan, A. (2015). Universal Design for Learning (UDL): Implications for Education. Paper presented at the Universal Design in Education Conference, Dublin, Ireland, 12-13 November

Hiranandani, V. (2005) 'Towards a Critical Theory of Disability in Social Work'. Critical Social Work, Vol. 6 (1). (WWW) http://www1.uwindsor.ca/criticalsocialwork/to wards-a-critical-theory-of-disability-in-socialwork (Accessed December 1st, 2013)

Holmberg, J., \& Samuelsson, B. (2006) Drivers and Barriers for Implementing Sustainable Development in Higher Education. UNESCO Education Sector. Education for Sustainable Development in Action. Technical Paper No. 3

Houghton, M. \& Fovet, F. (2012) 'Reframing Disability, reshaping the provision of services'. Communiqué, Vol. 13 (1), Page. 16-19

Howard, K. L. (2004). 'Universal design for learning: Meeting the needs of all students'. Learning and Leading with Technology, Vol. 31, Page. 26-29.

Ilieva, R., Beck, K., \& Waterstone, B. (2014). 'Towards sustainable internationalisation of higher education'. Higher Education, Vol. 68(6), Page 875-889

InterAcademy Council (2004) Inventing a Better Future: A Strategy for Building Worldwide Capacities in Science and Technology. InterAcademy Council.

Kelly, A., \& Hess, F. (2011) Beyond Retrofitting: Innovation in Higher Education. Hudson Institute Initiative on Future Innovation, Washington, DC

Kelly, K., \& van der Riet, M. (2001). 'Participatory research in community settings: Processes, methods and challenges'. In: M. Seedat, N. Duncan, \& S. Lazarus (Eds.), Community Psycho-

logy: Theory, Method and Practice. South African and Other Perspectives (Page. 159188). Cape Town: Oxford University Press

Ketschau, T. (2015) 'Social Justice as a Link between Sustainability and Educational Sciences'. Sustainability, Vol. 7, Page. 1575415771.

Kleemann, G.L. (2005) 'Weaving silos - a leadership challenge: A cross - functional team approach to supporting web - based student services'. New Directions for Student Services Special Issue: Technology in Student Affairs: Supporting Student Learning and Services, Vol. (112), Page. 89-101

Legrange, L. (2016) 'Decolonising the university curriculum: leading article', South African Journal of Higher Education, Vol. 30(2), Page 1-30

Leitch, S. and Palmer, I. (2010), 'Analysing Texts in Context: Current Practices and New Protocols for Critical Discourse Analysis in Organization Studies'. Journal of Management Studies, Vol. 47, Page 1194-1212

Lenz, B. K., Deshler, D. D., \& Kissam, B. R. (2004) Teaching Content to All: EvidenceBased Inclusive Practices in Middle and Secondary Schools. Boston, MA: Pearson Education.

Lloyd, C. (2016) 'Leading Across Boundaries and Silos in a Single Bound'. Community College Journal of Research and Practice, Vol. 40 (7), Page 607-614

Lovett, B., Nelson, J.M., Lindstrom, W. (2014) 'Documenting Hidden Disabilities in Higher Education: Analysis of Recent Guidance From the Association on Higher Education and Disability (AHEAD)', Journal of Disability Policy Studies, Vol 26 (1), Page $44-53$

Madaus, J. W. (2011) 'The History of Disability Services in higher education'. New Directions for Higher Education, Page 5-15. 
Meekosha, H., \& Soldatic, K. (2011) 'Human Rights and the Global South: the case of disability'. Third World Quarterly, Vol. 32 (8), Page 1383-1397

Mole, H. (2012) 'A US model for inclusion of disabled students in higher education settings: the social model of disability and Universal Design'. Widening Participation and Lifelong Learning, Vol. 14(3), Page 62-86

Mole, H. \& Fovet, F. (2013) 'UDL - From disabilities office to mainstream class: How the tools of a minority are addressing the aspirations of the student body at large'. Collected Essays on Learning and Teaching, Vol. 6, Page. 121-126.

Moore, J. (2005) 'Is higher Education ready for transformative learning? A question explored in the study of sustainability'. Journal of transformative Education, Vol. 3 (1), Page. 76-91.

Olssen, M., \& Peters, M. A. (2005). 'Neoliberalism, higher education and the knowledge economy: From the free market to knowledge capitalism'. Journal of Educational Policy, Vol. 20(3), Page. 313-345

Ralabate, P. K. (2011). Universal Design for Learning: Meeting the Needs of All Students . (WWW) The ASHA Leader. http://www.asha.org/Publications/leader/2011/ 110830/Universal-Design-for-Learning-Meeting-the-Needs-of-All-Students/

(Accessed December 1st, 2013)

Reason, P., \& Bradbury, H. (2001). 'Introduction: Inquiry and participation in search of a world

worthy of human aspiration'. In: P. Reason \& H. Bradbury (Eds.), Handbook of Action Research: Participative Inquiry and Practice (Page. 1-14). London: Sage

Reid, A., Petocz, P. (2006). 'University Lecturers' Understanding of Sustainability'. Higher Education, Vol. 51(1), Page 105-123

Rose, D. H., Harbour, W. S., Johnston, C. S., Daley, S. G., \& Abarbanell, L. (2006). 'Universal design for learning in postsecondary education: Reflections on

Cite this as:

Fovet, F. T Access, Universal Design and the Sustainability of Teaching Practices: a Powerful Synchronicity of Concepts at a Crucial Conjuncture for Higher Education. Indonesian Journal of Disability Studies (IJDS).2017:

Vol. 04(02): pp117-128 principles and their application'. Journal of Postsecondary Education and Disability, Vol. 19(2), Page. 17.

Rose, D. H., Meyer, A., \& Hitchcock, C. (2005) The Universally Designed Classroom: Accessible Curriculum and Digital Technologies. Cambridge, MA: Harvard Education Press.

Sadana, J. (2009) The Coding Manual for Qualitative Researchers. Sage, London.

Scholz, R., Lang, D., Wiek, A. et al. (2006) 'Transdisciplinary case studies as a means of sustainability learning: historical framework and theory'. International Journal of Sustainability in Higher Education, Vol. 7, Page. 226-51

Schroeder, C. (1999) 'Partnership: An imperative for enhancing student learning and institutional effectiveness'. New Directions for Higher Education, Vol. 87, Page. 5-18

Shulman, L. S., \& Shulman, J. H. (2007). 'How and what teachers learn: A shifting perspective'. Journal of Curriculum Studies, Vol. 36(2), Page 257-271

Sidhu, R. (2015). 'Using postcolonial scholarship to address equity in transnational higher education', Learning and Teaching, 8(1), Page 73-94

Smollan, R. (2011). 'Engaging with resistance to change'. University of Auckland Business Review. Vol. 13(1), Page. 12-15.

Snowden, D. (2000), 'The Art and Science of Story or Are You Sitting Uncomfortably? Part 1: Gathering and Harvesting the Raw Material', Business Information Review, Vol. 17(3), Page 147- 156.

Sterling, S. (2001) Sustainable Education Re-visioning Learning \& Change. Darlington Books.

Strange, C.C. and Banning, J.H. (2001) Educating by Design: Creating Campus Learning Environments that Work. San Francisco: Jossey-Bass. 
Sutton, J., \& Austin, Z. (2015). 'Qualitative Research: Data Collection, Analysis, and Management'. The Canadian Journal of Hospital Pharmacy, Vol. 68(3), Page 226-231.

Swail, W.S., Redd, K.E. and Perna, L.W. (2003) 'Retaining Minority Students in Higher Education: A Framework for Success'. ASHEERIC Higher Education Report, Vol. 30(2). San Francisco: Jossey-Bass.

Swain, J., \& French, S. (2000) 'Towards an affirmative model of disability', Disability and Society, Vol. 15 (4), Page. 569-82.

Swain, J., French, S., Barnes, C., \& Thomas, C. (Eds.) (2004) Disabling Barriers Enabling Environments. $2 \mathrm{~d}$ ed. London: SAGE.

Swap, W., Leonard, D., Shields, M., and Abrams, L. (2001) "Using mentoring and storytelling to transfer knowledge in the workplace", Journal of Management Information

Systems, Vol. 18(1), Page. 95-114

Swart, E. \& Pettipher, R. (2011), 'Perspectives on inclusive education', in E. Landsberg, D. Kruger \& E. Swart (eds.), Addressing barriers to learning in South Africa, Page 1-27, Van Schaik, Pretoria, South Africa

Tegmark-Chita, M., Gravel, J.W., Serpa, M. deL. B., Domings, Y., \& Rose, D.H. (2012) 'Using the Universal Design for Learning framework to support culturally diverse learners', Journal of Education, Vol. 192(1), Page. 17-22

Thurmond, V. (2001). 'The point of triangulation'. Journal of Nursing Scholarship, 33(3), Page. 254-256.

Tomlinson, C. A. (2001) How to Differentiate Instruction in Mixed Ability Classrooms (2nd ed.). Alexandria, VA: Association for Supervision and Curriculum Development.

Wagner, M., Cameto, R., \& Newman, L. (2003). 'Youth with disabilities: A changing Population'. A report of findings from the National Longitudinal Transition Study (NLTS) and the National Longitudinal Transition Study-2 (NLTS2). Menlo Park, CA: SRI International.

Wals, A. E. J. (2007). 'Introduction'. In Wals, A.E.J. (Ed.) Social Learning towards a Sustainable World. Principles, Perspectives, and Praxis (Page.17-32). Wageningen, The Netherlands: Wageningen Publishers -

Wals, A. \& Jickling, B. (2002),"“Sustainability” in higher education From doublethink and newspeak to critical thinking and meaningful learning", International Journal of Sustainability in Higher Education, Vol. 3(3), Page. 221 - 232 Weigel, Van B. (2002) Deep Learning for a Digital Age: Technology's Untapped Potential To Enrich Higher Education, San Francisco: Jossey-Bass. 